\title{
Detection of Babesia canis vogeli, Babesia gibsoni and Ehrlichia canis by multiplex PCR in naturally infected dogs in South India
}

\author{
Jose Jain, Bindu Lakshmanan*, Hitaishi V. Nagaraj, Jose E. Praveena, \\ Karunakaran Syamala, and Thazhathuveetil Aravindakshan
}

\author{
School of Applied Animal Production and Biotechnology, Department of Veterinary Parasitology, \\ College of Veterinary and Animal Sciences, Kerala Veterinary and Animal Sciences University, \\ Mannuthy, Thrissur, Kerala, India
}

\begin{abstract}
JAIN, J., B. LAKSHMANAN, H. V. NAGARAJ, J. E. PRAVEENA, K. SYAMALA, T. ARAVINDAKSHAN: Detection of Babesia canis vogeli, Babesia gibsoni and Ehrlichia canis by multiplex PCR in naturally infected dogs in South India. Vet. arhiv 88, 215-224, 2018.
\end{abstract}

\section{ABSTRACT}

Tick borne haemoparasites and haemorickettsiales pose a major health risk to animals worldwide. The present study reports the development and validation of multiplex PCR to simultaneously detect the most prevalent tick borne pathogens infecting dogs in Kerala, South India. The assay targeting the small subunit ribosomal RNA genes of the organisms could amplify well demarcated amplicons of B. canis vogeli, B. gibsoni and $E$. canis. In the study population, which included both healthy dogs as well as those with clinical symptoms suggestive of the three infections under study, $46.6 \%$ animals were infected with one of the three pathogens, amongst which the occurrence of $B$. gibsoni was significantly the highest. Natural co-infections were also detected in nine dogs, which suggests the suitability of the assay to assist in the selection of pathogen specific treatment protocols.

Key words: Multiplex PCR; Babesia canis vogeli; Babesia gibsoni; Ehrlichia canis

\section{Introduction}

Tick borne pathogens are an emerging problem worldwide. Canine babesiosis and ehrlichiosis are amongst the most prevalent vector borne haemo-parasites / rickettsiales of dogs in India. In South India, canine babesiosis have been reported in Tamil Nadu (SUNDAR et al., 2004; LAKSHMANAN and JOHN, 2007; SENTHILKUMAR et al., 2009) and Kerala, (SABU et al., 2002; KARUNAKARAN et al., 2011; TRESAMOL et al., 2013). Among the three subspecies of Babesia canis viz., B. canis canis, B. canis

\footnotetext{
*Corresponding author:
}

Bindu Lakshmanan, Phd., Assist. Prof., Department of Veterinary Parasitology, College of Veterinary and Animal Sciences, Mannuthy, Thrissur, Kerala, India-680651, Phone: +94 4748 6722; Fax: +487 2370 388, E-mail: bindul@kvasu.ac.in 
vogeli and B. canis rossi, (UILENBERG et al., 1989), only B. canis vogeli has been reported to infect dogs in Kerala state (AUGUSTINE et al., 2017). Among the different Babesia spp., the latter also recorded a higher proportion of B. gibsoni among the study population. Babesia gibsoni is mainly transmitted by Haemaphysalis longicornis and Rhipicephalus sanguineus ticks (SOLANO-GALLEGO and BANETH, 2011). Clinically, canine babesiosis is exhibited in a wide range of presentations from subclinical disease to serious illness characterised by fever, pallor, jaundice, splenomegaly, weakness and collapse, associated with intra and extra vascular haemolysis. Canine monocytic ehrlichiosis caused by Ehrlichia canis and transmitted by $R$. sanguineus, is also a febrile disease associated with lymphadenopathy, bone marrow suppression and pancytopenia.

Infections with multiple tick-transmitted pathogens may occur in animals in endemic areas, because the same tick species can be a vector of several pathogens (KLEDMANEE et al., 2009). Detection of concurrent infection is imperative in this context to ensure successful control. A single-step PCR assay to detect co-infection with three subspecies of B. canis (DUARTE et al., 2008), PCR-RFLP to detect and differentiate B. canis canis and $B$. canis vogeli (SOLANO-GALLEGO et al., 2008), multiplex PCR assay to detect E. canis, Babesia spp. and Hepatozoon canis (KLEDMANEE et al., 2009), multiplex quantitative real time assay for B. canis vogeli and E. canis (PELEG et al., 2010) are among the several more successful attempts to detect multiple infection with vectorborne canine pathogens.

Concurrent infections of babesiosis and ehrlichiosis are not uncommon in South India (LAKSHMANAN and JOHN, 2007). It is noteworthy that effective therapeutic protocols for $B$. canis, B. gibsoni and E. canis involve the use of different drug combinations and hence warrant the need to sensitively detect concurrent infections at an early stage. Multiplex PCR, for detection of B. canis, B. gibsoni and E. canis in a single assay, could be useful for sensitive detection, selection of specific treatment for each disease and to assess the clearance of the organisms after treatment. This paper describes a multiplex PCR protocol targeting the simultaneous amplification of the small subunit ribosomal RNA of the three most prevalent tick borne pathogens of dogs in South India.

\section{Materials and methods}

Sample collection. Whole blood samples $(\mathrm{n}=150)$ collected from dogs with clinical symptoms suggestive of babesiosis/ehrlichiosis $(n=65)$, as well as from apparently healthy dogs $(n=85)$ from different parts of Kerala, South India, formed the material for the study. Thin peripheral blood smears stained by Giemsa's method were microscopically examined to identify the presence of Babesia spp. and Ehrlichia spp.

Molecular analysis. DNA extraction was done from whole blood with anticoagulant added by the phenol chloroform method (SAMBROOK and RUSSELL, 2001) with 
modifications (ARAVINDAKSHAN et al., 1998) as well as by using DNeasy Blood \& Tissue Kit (QIAGEN, Germany). The quality of DNA in the final elutes were estimated using a nanospectrophotometer (Nano drop 2000 C, Thermo-scientific, USA). Samples which yielded a ratio between 1.7 and 1.9 at 260:280 nm were selected for analysis.

The PCR reaction mixture and gradient cycling conditions were initially standardized using a known positive blood DNA sample, as revealed by heavy parasitaemia during microscopic examination of stained blood smears. The primers targeting 18S rRNA of B. canis and 16S rRNA of E. canis were selected as per DUARTE et al. (2008) and GAL et al. (2008) respectively. The primers targeting the 18S rRNA gene of $B$. gibsoni were designed using Primer 3 software (), utilizing the corresponding sequence of $B$. gibsoni isolate available in the GenBank (Accession No. KP 901263). The suitability was checked with sequence manipulation suite software (www.bioinformatics.org $>$ sms 2 ) and specificity confirmed by blast analysis (BLASTntool : www.ncbi.nlm.nih.gov). The primers are listed in Table 1 . The multiplex PCR was performed in a $30 \mu \mathrm{L}$ reaction volume containing $3.0 \mu \mathrm{L}$ of buffer (10X) without $\mathrm{MgCl}_{2}, 500 \mu \mathrm{M}$ each of dNTP, $25 \mathrm{pmol}$ each of forward and reverse primers, $2.0 \mathrm{mM}$ of $\mathrm{MgCl}_{2}, 1.5 \mathrm{U}$ of $\mathrm{Taq}$ DNA polymerase and $6.0 \mu \mathrm{L}$ of template DNA. All the reagents were procured from Sigma Aldrich (USA). A no template control (NTC) was included in each run. A gradient thermal cycling program ((Bio-Rad T100, USA) was adopted, with initial denaturation at $94{ }^{\circ} \mathrm{C}$ for 5 min followed by 35 cycles of denaturation $\left(94{ }^{\circ} \mathrm{C}, 30 \mathrm{~s}\right)$, annealing $\left(52{ }^{\circ} \mathrm{C}\right.$ to $\left.60^{\circ} \mathrm{C}, 30 \mathrm{~s}\right)$ and extension $\left(72{ }^{\circ} \mathrm{C}, 1 \mathrm{~min}\right.$ ) and a final extension at $72{ }^{\circ} \mathrm{C}$ for $5 \mathrm{~min}$. The amplified PCR products were subjected to electrophoresis in 3\% agarose gel (Hoefer, USA) and visualised in Geldocumentation system (Bio-Rad Laboratories, USA). The amplicons were purified using silica gel purification columns (GeneJET, Thermoscientific), sequenced using the Sangers dideoxy chain termination method and the sequences were aligned using Sequencher Version 5.0 (Sci Genom Labs Pvt Ltd, Cochin).

Table 1. Primers used for the study

\begin{tabular}{|l|l|l|}
\hline S1 No. & \multicolumn{1}{|c|}{ Organism } & \multicolumn{1}{c|}{ Primer sequence } \\
\hline 1 & Babesia canis vogeli & $\begin{array}{l}\text { BAB1 F: 5'- GTG AAC CTT ATC ACT TAA AGG-3' } \\
\text { BAB4 R: 5'- CAA CTC CTC CAC GCA ATC G-3' }\end{array}$ \\
\hline 2 & B. gibsoni & $\begin{array}{l}\text { BAGI F: 5'- TTG GCG GCG TTT ATT AGT TC-3' } \\
\text { BAGI R: 5'- AAA GGG GAAAAC CCC AAA AG-3' }\end{array}$ \\
\hline 3 & Ehrlichia canis & $\begin{array}{l}\text { ECA F: 5'-AAC ACA TGC AAG TCG AAC GGA-3' } \\
\text { HE3R: 5'- TAT AGG TAC CGT CAT TAT CTT CCC TAT-3' }\end{array}$ \\
\hline
\end{tabular}




\section{Results}

Individual amplification reactions with known positive controls of $B$. canis vogeli, $B$. gibsoni and E. canis yielded specific PCR products of approximately $600 \mathrm{bp}, 488 \mathrm{bp}$, and 412 bp sizes respectively. Positive PCR signals were not generated in any of the negative control samples. Further, there was no cross amplification of the species, thus confirming the specificity of the protocol. Sequence analysis of the three amplicons by BLAST tool against the respective published sequences in GenBank confirmed the identity of each sequence. Multiplex PCR standardized for simultaneous detection of natural infections of B. canis vogeli, B. gibsoni and E. canis generated specific and well demarcated amplicons at an optimum annealing temperature of $59{ }^{\circ} \mathrm{C}$, when the DNA of known positive controls of these three pathogens were mixed to yield the template sample (Fig. 1). This protocol was further applied to the test DNA samples $(n=150)$ to validate the protocol, as well as to generate data on the true prevalence of infection among dogs in Kerala.

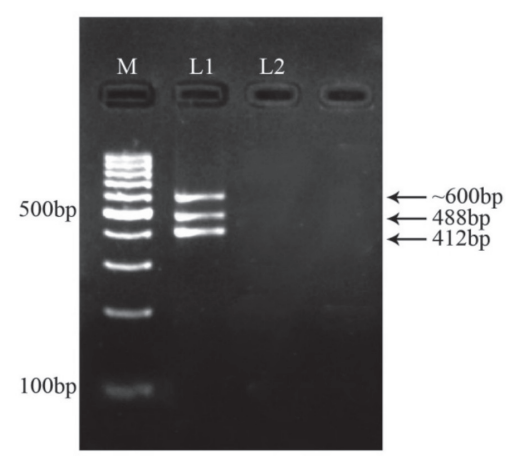

Fig. 1. Multiplex PCR products of B. canis, B. gibsoni and E. canis. M: 100bp DNA ladder, L1: Positive samples, L2: NTC

Blood smear examination could detect infection with either of these tick-borne pathogens in $28 \%$ of animals, while multiplex PCR assay revealed $46.6 \%(70 / 150)$ of sampled dogs to be positive (Table 2), which signalled the higher sensitivity of the latter to detect these pathogens during natural infections. Amongst these, a higher percentage of B. gibsoni (26\%) infection was noted followed by B. canis vogeli $(10.7 \%)$ and $E$. canis $(4 \%)$. There was a large statistically significant difference in the prevalence of $B$. gibsoni (Cal $\chi^{2}>$ Table $\chi^{2}$ at $1 \%$ level). However, by conventional microscopy, piroplasms of B. canis and B. gibsoni were observed in $10 \%$ and $16.6 \%$ of the study population respectively, while inclusion bodies of E. canis could be detected in only $1.3 \%$ of the samples (Fig. 2). 
J. Jain et al.: Multiplex PCR for detection of Babesia canis vogeli, B. gibsoni and Ehrlichia canis

Table 2. Number of dogs infected with tick borne pathogens

\begin{tabular}{|l|c|c|c|}
\hline \multirow{2}{*}{\multicolumn{2}{|c|}{ Nature of infection }} & Pathogen species detected in dogs by multiplex PCR \\
\cline { 2 - 4 } & B. canis vogeli & B. gibsoni & E. canis \\
\hline Single infection & 16 & $39 *$ & 6 \\
\hline Coinfection with & \multicolumn{3}{|c|}{} \\
\hline B. canis vogeli & - & 3 & 5 \\
\hline B. gibsoni & 3 & - & - \\
\hline E. canis & 0 & 1 & 1 \\
\hline
\end{tabular}

* Highly significant $\left[\mathrm{Cal} \chi^{2}>\right.$ Table $\left.\chi^{2}(1 \%)\right]$

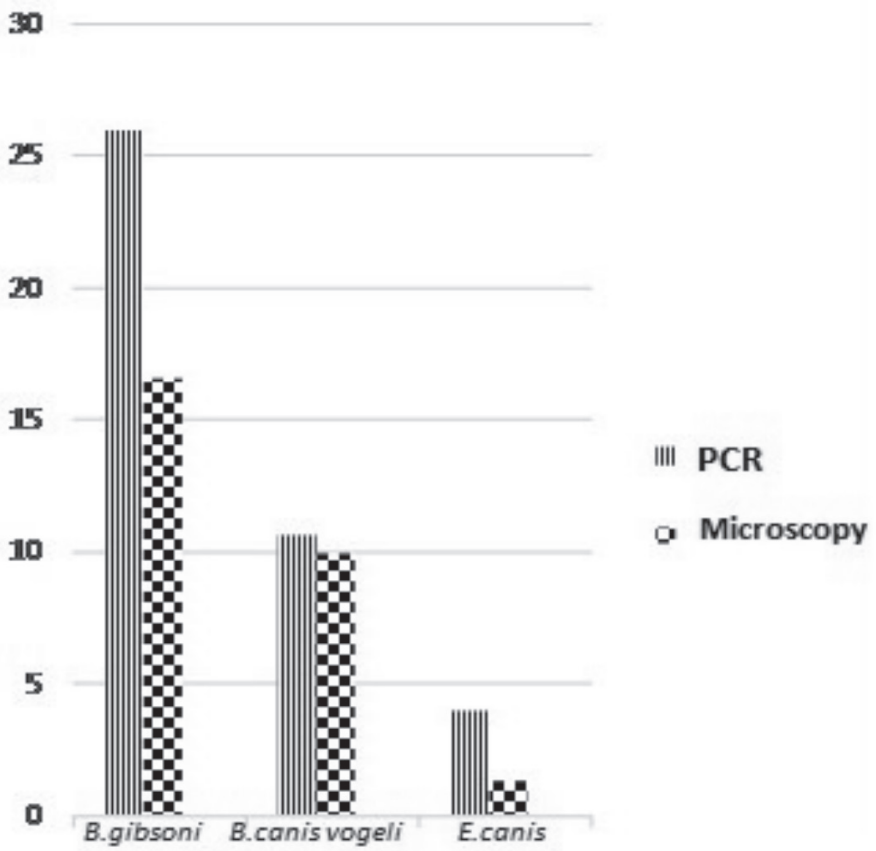

Fig. 2. Comparison of PCR and microscopy for pathogen detection 


\section{J. Jain et al.: Multiplex PCR for detection of Babesia canis vogeli, B. gibsoni and Ehrlichia canis}

Multiplex PCR assay also proved to be useful in detecting natural co-infections with these pathogens. Concurrent infection with E. canis and B. canis vogeli (3.3\%), B. gibsoni with $B$. canis vogeli $(2 \%)$ and with $E$. canis $(0.66 \%)$ could be detected with the PCR assay. It is noteworthy that co-infection could not be detected during blood smear examination. Among the three pathogens, the occurrence of B. gibsoni was the highest in this study by multiplex PCR as well as by conventional microscopy. The multiplex PCR could detect canine babesiosis and ehrlichiosis with $82.72 \%$ and $92.6 \%$ specificity, respectively, while the sensitivity was $100 \%$ (Table 3 ).

Table 3. Sensitivity and specificity analysis of multiplex PCR

\begin{tabular}{|l|c|c|}
\hline Technique & Staining positive & Staining negative \\
\hline Babesia spp. & 40 & 19 \\
\hline PCR Positive & 0 & 91 \\
\hline PCR Negative & 1 & 11 \\
\hline Ehrlichia canis & 0 & 138 \\
\hline PCR Positive & & \\
\hline PCR Negative &
\end{tabular}

\section{Discussion}

Multiplex PCR assay, used to detect co-infection of pathogenic organisms prevalent in a geographical area, is a rapid and accurate tool to assess the epidemiological status of infection. There are several published studies on the detection of co-infection with subspecies of Babesia in dogs, utilising different PCR based assays and its higher sensitivity in detecting organisms is compared to conventional techniques (MATJILA et al., 2004 ; DUARTE et al., 2008; SOLANO-GALLEGO et al., 2008; COSTA-JUNIOR et al., 2012; KAMANI et al., 2013). Perusal of the literature suggested that multiplex PCR had not been attempted in India for identifying B. canis vogeli, B. gibsoni and E. canis, though co-infection of $B$. canis vogeli with $E$. canis, as well as with $H$. canis has been detected among dogs in North, North East and Central India by separate PCR assays (RANI et al., 2011). SINGH et al. (2014) surveyed 214 blood samples of dogs in North West India by conventional microscopy, and reported an overall prevalence of $7.47 \%$ Babesia spp. infection, among which the proportion of $B$. gibsoni was significantly the highest (6.34\%). In spite of several records of canine babesiosis in South India based on microscopic examination of peripheral blood smears, the infection had been thoroughly underestimated in this area until AUGUSTINE et al. (2017) revealed the presence of Babesia spp. in 57\% of clinically suspected dogs (46/80) using semi nested PCR. They also observed a higher sensitivity for the PCR assay in comparison to microscopic detection 
of piroplasms in stained blood smears. A retrospective study of canine haemoprotozoa in Tamil Nadu during 2006-2011, as reported by conventional microscopic detection, also revealed a higher prevalence of B. gibsoni $(56.67 \%)$ followed by E. canis $(23.21 \%)$ (VAIRAMUTHU et al., 2014). In this context, the development of a sensitive tool, for detection of multiple pathogen species associated with canine babesiosis and ehrlichiosis, assumes significance. Multiplex PCR for simultaneous detection of the most prevalent tick borne canine pathogens, viz., B. canis vogeli, B. gibsoni and E. canis, successfully validated in the present study, could serve to detect co-infections in endemic areas. The assay had higher sensitivity when compared to blood smear examination.

In the present survey population, which included both healthy dogs and those with clinical symptoms suggestive of the three infections under study, babesiosis was detected in $42.66 \%$ animals. Different reports based on molecular assays conducted in babesiosis endemic countries revealed a sample prevalence that ranged from 0.01 to 6.6\% (CRIADO-FORNELIO et al., 2003; DUH et al., 2004; INOKUMA et al., 2004; BIRKENHEUR et al., 2005; OYAMADA et al., 2005; M'GHIRBI and BOUATTOUR, 2008). Our studies support and confirm that canine babesisois is endemic in this State of South India, with a significantly higher proportion of animals harbouring $B$. gibsoni, the small babesial piroplasm. Babesia canis, the large babesial piroplasm could be detected only in clinically suspected dogs, by both PCR and conventional microscopic techniques without a significant difference in sensitivity. In contrast, B. gibsoni could be detected by multiplex PCR in both suspected as well as healthy animals, indicating the possibility of carrier status for this pathogen in endemic areas. The higher sensitivity of multiplex PCR when compared to conventional microscopy for detecting B. gibsoni and E. canis infection needs considerable attention. Molecular evidence of $E$. canis, either as single or as concurrent infection, provided by the multiplex PCR assay also revealed that the prevalence of canine ehrlichiosis is low in this south-western state, compared to the neighbouring state of Tamil Nadu (RAJAGOPAL et al., 2004 ; LAKSHMANAN et al., 2007). These authors also established the higher sensitivity of PCR assays for detection of natural E. canis infections. Moreover, the results of the present study also demonstrated remarkable variations in the endemicity patterns of canine tick borne pathogens in south India.

The multi-pathogen detection assay was able to identify co-infection in nine dogs under field conditions. The higher occurrence of concurrent infections of $B$. canis and $E$. canis could be attributed to the existence of a common vector for these pathogens. Coinfections with more than one pathogen could partially explain variations in pathogenicity, clinical presentation, and response to therapy during natural infections. The technique not only reduces the time and cost involved in detecting multiple pathogens with superior sensitivity, but also holds promise as a valuable clinical tool to facilitate selection of 
the appropriate treatment protocol during concurrent infections. The assay could be adopted to assess the carrier status of ticks in a particular geographical area, to map the epidemiological status of haemoparasitic and haemorickettsiales.

\section{Acknowledgements}

The authors are grateful to the Government of Kerala for providing financial assistance through the State Plan funds 15-16 (RSP/15-16/VI-10) and to Kerala Veterinary and Animal Sciences University, for the technical support.

\section{References}

ARAVINDAKSHAN, T. V., A. M. NAINAR, K. NACHIMUTHU (1998): Extraction of DNA from cattle blood cells. Cheiron 27, 5-6.

AUGUSTINE, S., L. SABU, B. LAKSHMANAN (2017): Molecular identification of Babesia spp. in naturally infected dogs of Kerala, South India. J. Parasit. Dis. 41, 459-462.

BIRKENHEUR, A. J., M. G. LEVY, E. B. BREITSCHWERDT (2005): Development and evaluation of seminested PCR for detection and differentiation of Babesia gibsoni (Asian genotype) and B. canis DNA in canine blood samples. J. Clin. Microbiol. 41, 4172-4177.

COSTA-JUNIOR, L. M., M. ZAHLER- RINDER, M. F. B. RIBEIRO, K. REMBECK, E. M. L. RABELO, K. PFISTER, L. M. F. PASSOS (2012): Use of a Real time PCR for detecting subspecies of Babesia canis. Vet. Parasitol. 188, 160-163.

CRIADO-FORNELIO, A., A. MARTINEZ- MARCOS, A. BULING-SARANA, J. C. BARBACARRETERO (2003): Molecular studies on Babesia, Theileria and Hepatozoon in southern Europe Part 1. Epizootiological aspects. Vet. Parasitol. 113, 189-201.

DUARTE, S. C., G. F. C. LINHARES, T. N. ROMANOWSKY, O. NETO, L. M. F. BORGES (2008): Assessment of primers designed for the subspecies-specific discrimination among Babesia canis canis, Babesia canis vogeli and Babesia canis rossi by PCR assay. Vet. Parasitol. 152, 16-20.

DUH, D., N. TOZON, M. PETROVEC, K. STRASEK, T. AVISC-ZUPANC (2004): Canine babesiosis in Slovenia: Molecular evidence of Babesia canis canis and B. canis vogeli. Vet. Res. 35, 363-368.

GAL, A., E. LOEB, Y. YISASCHAR- MEKUZAS, G. BANETH (2008): Detection of Ehrlichia canis by PCR in different tissues obtained from dogs surveyed for naturally occurring canine monocytic ehrlichiosis. Vet. J. 175, 212-217.

INOKUMA, H., Y. YOSHIZAKI, K. MATSUMOTO, M. OKUDA, T. ONISHI, K. NAKAGOME, R. KOSUGI, M. HIRAKAWA (2004): Molecular survey of Babesia infection in dogs in Okinawa, Japan. Vet. Parasitol. 121, 341-346.

KAMANI, J., G. BANETH, Y. MUMCUOGLU, N. E. WAZIRI, O. EYAL, Y. GUTHMANN, S. HARRUS (2013): Molecular detection and characterization of tick-borne pathogens in dogs and ticks from Nigeria. PLoS Negl. Trop. Dis. 7, 108-115. 
J. Jain et al.: Multiplex PCR for detection of Babesia canis vogeli, B. gibsoni and Ehrlichia canis

KARUNAKARAN. S., U. N. PILLAI, H. P. SASIDHARAN (2011): Babesia gibsoni infection in a German Shepherd dog. Vet. World 4, 269-270.

KLEDMANEE, K., S. SUWANPAKDEE, S. KRAJANGWONG, J. CHATSIRIWECH, P. SUKSAI, P. SUWANNACHAT, L. SARIYA, R. BUDDHIRONGAWATR, P. CHAROONRUT, K. CHAICHOUN (2009): Development of multiplex polymerase chain reaction for detection of Ehrlichia canis, Babesia spp. and Hepatozoon canis in canine blood. Southeast Asian J. Trop. Med. Public Hlth. 40, 35-39.

LAKSHMANAN, B., L. JOHN (2007): Clinical findings and concurrent infections in canine ehrlichiosis. Indian Vet. J. 84, 863-864.

LAKSHMANAN, B., L. JOHN, S. GOMATHINAYAGAM, G. DHINKAR RAJ (2007): Specific Amplification of $E$. canis DNA from naturally infected dogs in India. Vet arhiv. 77, 307-312.

MATJILA, P. T., B. L. PENZHORN, C. P. J. BEKKER, A. M. NIJHOF, F. JONGEJAN (2004): Confirmation of occurrence of Babesia canis vogeli in domestic dogs in South Africa. Vet. Parasitol. 122, 119-125.

M'GHIRBI, Y., A. BOUATTOUR (2008): Detection and molecular characterization of Babesia canis vogeli from naturally infected dogs and Rhipicephalus sanguineus ticks in Tunisia. Vet. Parasitol. 152, 1-7.

OYAMADA, M., B. DAVOUST, M. BONI, J. DEREURE, B. BUCHETON, A. HAMMADA, K. ITAMOTO, M. OKUDA, H. INOKUMA (2005): Detection of Babesia canis rossi, B. canis vogeli and Hepatozoon canis in dogs in a village of Eastern Sudan by using a screening PCR and sequencing methodologies. Clin. Diagn. Lab. Immunol. 12, 1343-1346.

PELEG, O., G. BANETH, O. EYAL, J. INBAR, S. HARRUS (2010): Multiplex real-time qPCR for the detection of Ehrlichia canis and Babesia canis vogeli. Vet. Parasitol. 173, 292-299.

RAJAGOPAL, A., S. A. BASITH, S. GOMATHINAYAGAM, G. DHINKAR RAJ (2004): One tube nested PCR for the diagnosis of canine ehrlichiosis. J. Vet. Parasitol. 18, 67-68.

RANI, A. P. A., P. J. IRWIN, G. T. COLEMAN, M. GATNE, R. J. TRAUB (2011): A survey of canine tick-borne diseases in India. Parasit. Vectors. 4, 141.

SABU, L., P. G. BABY, S. AJITH KUMAR, K. DEVADA (2002): Babesia canis infections in young pups. Intas Polivet. 3, 129-130.

SAMBROOK, J., D. W. RUSSELS (2001): Molecular Cloning - A Laboratory Manual. $3^{\text {rd }}$ ed. Cold Spring Harbor Laboratory Press. New York. pp. 6, 11.

SENTHILKUMAR, K., S. VAIRAMUTHU, D. KATHIRESAN (2009): Prevalence of haemoprotozoans in canines in Chennai city. Tamilnadu J Vet Anim Sci. 5, 104-108.

SINGH, A., H. SINGH, N. K. SINGH, N. D. SINGH, S. S. RATH (2014): Canine babesiosis in northwestern India: Molecular detection and assessment of Risk Factors. Biomed Res. Int. 11, $1-5$.

SOLANO-GALLEGO, L., G. BANETH (2011): Babesiosis in dogs and cats - expanding parasitological and clinical spectra. J. Vet. Parasitol. 181, 48-60. 
J. Jain et al.: Multiplex PCR for detection of Babesia canis vogeli, B. gibsoni and Ehrlichia canis

SOLANO-GALLEGO, L., M. TROTTA, E. CARLI, B. CARCY, M. CALDIN, T. FURLANELLO (2008): Babesia canis canis and Babesia canis vogeli clinicopathological findings and DNA detection by means of PCR-RFLP in blood from Italian dogs suspected of tick-borne disease. Vet. Parasitol. 157, 211-221.

SUNDAR, N., C. BALACHANRAN, A. SENTHILVELAN (2004): Incidence of Babesia gibsoni infection in dogs in Tamil Nadu. J. Vet. Parasitol. 18, 79-80.

TRESAMOL, P. V., U. N. PILLAI, J. ANUMOL, K. DEVADA, M. R. SASEENDRANATH (2013): Cerebral babesiosis due to Babesia gibsoni in a dog - a case report. J. Vet. Anim. Sci. 44, 85-86.

UILENBERG, G., F. F. J. FRANSEEN, N. M. PERIE, A. A. M. SPANJER (1989): Three groups of Babesia canis distinguished and a proposal for nomenclature. Vet. Quart. 11,33-40.

VAIRAMUTHU, S., R. S. RANJU, B. R. LATHA, B. DHIVYA, C. BALACHANDRAN (2014): A six year retrospective study of haemoprotozoan parasites affecting dogs in Chennai, Tamil Nadu, India. J. Parasit. Dis. 38, 193-195.

Received: 29 December 2016

Accepted: 13 October 2017

JAIN, J., B. LAKSHMANAN, H. V. NAGARAJ, J. E. PRAVEENA, K. SYAMALA, T. ARAVINDAKSHAN: Dokaz vrsta $B$. canis vogeli, $B$. gibsoni i $E$. canis višestrukim PCR-om u prirodno inficiranih pasa u Južnoj Indiji. Vet. arhiv 88, 215-224, 2018.

\section{SAŽETAK}

Krvni paraziti i rikecije podrijetlom iz krpelja glavna su opasnost za zdravlje životinja diljem svijeta. U ovom je istraživanju razvijen i validiran višestruki PCR za istodobno dokazivanje najčešćih uzročnika koje na pse prenose krpelji u Kerali u Južnoj Indiji. Malim ciljnim subjediničnim ribosomskim RNA mogli su proizvesti jasno razlučivi produkti specifični za $B$. canis vogeli, B. gibsoni i E. canis. U pretraživanoj populaciji koja je obuhvaćala zdrave pse i one s kliničkim znakovima, koji su upućivali na infekciju uzrokovanu jednim od spomenutih uzročnika, 46,6 \% životinja bilo je inficirano jednim od njih triju. Infekcija vrstom $B$. gibsoni bila je znatno češća. Prirodna je koinfekcija dokazana u devet pasa, što potvrđuje prikladnost testa za dijagnostiku i njegovo značenje pri poduzimanju odgovarajućeg liječenja.

Ključne riječi: višestruki PCR; Babesia canis vogeli; Babesia gibsoni; Ehrlichia canis 